DOI https://doi.org/10.18551/rjoas.2021-02.09

\title{
FACTORS AFFECTING THE INTENTION TO USE FASHION-RENTING PLATFORM
}

\author{
Barkah Wira Tri, Suroso Arif Imam, Hermadi Irman \\ Business School, IPB University, Indonesia \\ ${ }^{\star}$ E-mail: wiratribarkah@gmail.com
}

\begin{abstract}
The sharing economy is an economic model defined as a peer-to-peer (P2P) based activity of acquiring, providing, or sharing access to goods and services that is often facilitated by a community-based on-line platform. Fashion-renting platform is one of the sharing economy platforms that are currently developing. The development of a fashion-renting platform is expected to be an alternative solution to meet the fashion needs of consumers in Indonesia. The purpose of this study is to identify the factors that influence the intention to use fashionrenting platform. This study combines TAM and IS Success model to identify the relationship and influence between variables. A total of 173 respondents have filled out an online questionnaire distributed through several media with the criteria of the female population in the Greater Jakarta area who have never used a fashion rental platform. The endogenous variable $(Z)$ in this study is the intention to use or intention to use. The intervening variable (Y) in this study includes user satisfaction (US) and consumer attitude (ATT). The exogenous variable $(X)$ in this study includes information quality (IQ), system quality (SQ), perceived usefulness (PU) and perceived ease of use. The results showed that the latent variable system quality has no significant effect on user satisfaction while the latent variable information quality has a significant effect on user satisfaction. The latent variables, perceived usefulness and perceived ease of use, both have a significant effect on attitude, this means that if the consumer's perception of the benefits and convenience of using a fashion-renting platform is good, then this will have a positive impact on the user's attitude. In addition, the latent variable, perceived ease of use also has a significant effect on perceived usefulness. Then the latent variables, perceived usefulness and user satisfaction, both have no significant effect on intention to use, while the attitude variable has a significant effect on intention to use.
\end{abstract}

\section{KEY WORDS}

Sharing economy, fashion-renting, TAM, IS success model.

Excessive consumption of fashion goods has become our challenge today (Armstrong et al. 2015). We can see more and more consumers who continuously shop for fashion items even outside of their needs to follow the current trends. Excessive consumption and a culture of waste have resulted in more premature disposal of clothing and more textile waste than ever before (Birtwistle and Moore, 2007). Another fact is, as the human population increases, the need for clothing will also increase. In addition, nowadays it is even easier to make buying and selling transactions online through e-commerce platforms. Therefore, if this consumer-shopping pattern is not well controlled, it will cause the potential for waste from fashion goods to continue to increase.

We can experience the development of the sharing economy platform in Indonesia in various business fields including the fashion industry. One of the fashion business models that is currently developing is a fashion rental platform. The rental business is defined as a transaction that provides access to consumers to use certain goods or services without having to own the product. The rental business is a trend that is currently being developed in the community (Bardhi and Eckhardt, 2012). Allied Market Research conducted a study on the projection of the fashion rental business until 2023. The results of this research showed that fashion renting is an attractive option for individual style lovers who do not have enough money to buy the fashion products they want. These fashion products include everyday clothes such as tops and pants, party dresses, to wedding dresses. The choice of renting 
clothes is expected to have a positive impact on the surrounding environment. By renting, consumers have played an active role to help reduce textile waste, which continues to increase every day.

Consumer perception is an important factor to consider when adopting a technology. The Technology Acceptance Model (TAM) developed by Davis (1989) can be used to explain and predict the behavior of receiving information technology, which in this case is a fashion rental platform. According to TAM, perceived usefulness and perceived ease of use are two factors that influence attitudes. TAM believes that behavioral intention has a significant positive effect. According to TAM, perceived usefulness and perceived ease of use are two factors driving the action. In addition, the quality of the information system is another important factor for consumers when using a fashion rental platform. DeLone and McLean IS success model (D\&M model) is the most widely used and reliable model for understanding the use of information systems (IS) and its success (DeLone and Mclean, 1992). This model uses two quality dimensions, namely, information quality and system quality as independent variables. This study will combine the principles of the TAM and D\&M models, and apply them to a fashion rental platform service to test and analyze the relationship between consumer perceptions, service quality, customer satisfaction, consumer attitudes and intention to use a fashion rental platform.

\section{METHODS OF RESEARCH}

The study was conducted for three months from December 2019 to February 2020. Primary data were obtained through the distribution of online questionnaires aimed at respondents who have never used a fashion-renting platform.

The sampling technique used in this study was purposive sampling. A total of 173 respondents have filled out an online questionnaire distributed through several media with the criteria of the female population in the Greater Jakarta area who have never used a fashion-renting platform. All of respondents were met the criteria.

Primary data collection is done using an instrument in the form of an online questionnaire with the help of Google Form. Types of questions in this research consisted of both open-ended and close-ended questions. The questionnaire was divided into three parts: screening, respondent profile, and the main questions related to research variables.

Respondent profile data includes age, status, domicile, last education, occupation, and monthly income. The scale used is a likert scale with five levels, namely (1) strongly disagree, (2) disagree, (3) quite agree, (4) agree, and (5) strongly agree. Indicator variables used in this study are replications of the model used in the study of Davis (1989) and DeLone and McLean (1992).

The reliability test of each variable in this study was measured using Cronbach's alpha so that inconsistent indicators could be detected (Malhotra, 2010). The test results show the Cronbach alpha coefficient on each variable above 0.60 which indicates that all variables are reliable namely system quality (SQ) 0.84 , information quality (IQ) 0.86 , perceived usefulness (PU) 0.88, perceived ease of use (PEOU) 0.91, user satisfaction (US) 0.91, attitude (ATT) 0.89 , and intention to use (BIU) 0.80 .

Descriptive analysis has been applied using the average score and percentage method. Descriptions of indicator variables are grouped as agree and disagree answers. Answers (1) strongly disagree and (2) disagree are classified as disagreeing answers, and answers (3) quite agree, (4) agree and (5) strongly agree are classified as agreeing on answers. Variables and hypotheses in this study were analyzed using the Structural Equation Modeling (SEM) with the help of SmartPLS software.

\section{RESULTS OF STUDY}

Location of the research and data collection of respondents was carried out in the Greater Jakarta area of the female population who had never used a fashion-renting platform. The number of samples used in this study was 173 respondents. Demographic data 
of respondents based on age, status, domicile, education level, job category and monthly income are listed in the below table.

Table 1 - Demographic Data of Respondents

\begin{tabular}{|c|c|c|}
\hline Category & Frequency & Percentage \\
\hline \multicolumn{3}{|l|}{ Age Group (Years) } \\
\hline$<20$ & 8 & $5 \%$ \\
\hline $21-25$ & 91 & $53 \%$ \\
\hline $26-30$ & 62 & $36 \%$ \\
\hline $31-35$ & 9 & $5 \%$ \\
\hline$>35$ & 3 & $2 \%$ \\
\hline \multicolumn{3}{|l|}{ Status } \\
\hline Married & 43 & $25 \%$ \\
\hline Unmarried & 130 & $75 \%$ \\
\hline \multicolumn{3}{|l|}{ Domicile } \\
\hline Bekasi & 19 & $11 \%$ \\
\hline Bogor & 26 & $15 \%$ \\
\hline Depok & 17 & $10 \%$ \\
\hline Jakarta & 81 & $47 \%$ \\
\hline Tangerang & 15 & $9 \%$ \\
\hline South Tangerang & 15 & $9 \%$ \\
\hline \multicolumn{3}{|l|}{ Education Level } \\
\hline Senior High School & 17 & $10 \%$ \\
\hline Diploma (D3) & 10 & $6 \%$ \\
\hline S1/ Bachelor & 132 & $76 \%$ \\
\hline S2 Master Degree & 14 & $8 \%$ \\
\hline \multicolumn{3}{|l|}{ Occupation } \\
\hline Doctor & 2 & $1 \%$ \\
\hline Dentist & 20 & $12 \%$ \\
\hline Freelancers & 1 & $1 \%$ \\
\hline Private Employees & 82 & $47 \%$ \\
\hline State-Owned Enterprises & 3 & $2 \%$ \\
\hline Civil Servants & 12 & $7 \%$ \\
\hline Students & 31 & $18 \%$ \\
\hline Entrepreneurs & 10 & $6 \%$ \\
\hline Unemployment & 12 & $7 \%$ \\
\hline \multicolumn{3}{|l|}{ Income Categories } \\
\hline$<=$ IDR 5 million & 87 & $50 \%$ \\
\hline IDR. 6 - 10 million & 64 & $37 \%$ \\
\hline IDR. 11 - 15 milion & 17 & $10 \%$ \\
\hline IDR. 16 - 20 million & 3 & $2 \%$ \\
\hline$>=$ IDR 20 million & 2 & $1 \%$ \\
\hline
\end{tabular}

Estelami (1998) argues that demographic characteristics such as age and income are often thought to have an influence on product knowledge, shopping experience, and general purchasing behavior in most product or service categories, and are often used as the basis for segmentation market. In this case, the tenant is perceived as consumers who buy products in the form of clothes that are rented.

Based on the age group, the majority of respondents were 53 percent between 21 to 25 years, followed by the 26 to 30 years at 36 percent. The age of the youngest respondent in this study is 18 years, while the age of the oldest respondent is 42 years. Based on status, the majority of respondents are unmarried as many as 130 people or 75 percent of the total respondents. Based on domicile, the majority of respondents came from DKI Jakarta with a total of 81 respondents or 47 percent of the total respondents.

Based on the latest education level, respondents with a bachelor background dominated with 132 respondents or 76 percent of the total respondents. Respondents with a high school and equivalent were in the second place as many as 17 respondents or 10 
percent. Furthermore, the category of respondents with a master's education background is in $3 r d$ with a total of 14 respondents or 8 percent of the total respondents. Meanwhile, respondents with a diploma background were 10 respondents or 6 percent of the total respondents and as many as 2 respondents or 1.83 percent.

Based on job categories, respondents are divided into 9 job categories, namely doctors, dentists, freelancers, private employees, state-owned enterprises, civil servants, students, entrepreneurs and unemployment. The data obtained shows that the majority of respondents as many as 82 respondents or 47 percent of the total respondents are private employees followed by the student as many as 31 respondents or about 18 percent of the total respondents. In third place, dentists were 20 respondents or 12 percent of the total respondents, followed by civil servants and unemployment respondents, respectively, as many as 12 people or 7 percent. State-owned enterprises are in 5th place as many as 3 respondents or 2 percent of the total respondents, while in the last are doctors as many as 2 respondents and freelancers as many as 1 respondent or about 1 percent each. Respondents were divided into 5 income categories per month, from $<=$ IDR 5 million, IDR. 6 - 10 million, IDR. 11-15 million, IDR.16-20 million, and >= 20 million per month. As many as 87 respondents or about 50 percent of the total respondents had an income of less than IDR 5 million per month followed by the income category from IDR 6 to 10 million as many as 64 respondents or 37 percent, and the income category IDR 11 to 15 million as many as 17 respondents or about 10 percent of total respondents. The income category from IDR 16 to 20 million were 3 respondents or about 3 percent and the last was 2 respondents with an income more than IDR 20 million or about 2 percent of the total respondents.

The results of the research survey regarding system quality (SQ) indicators are presented in Table 4. Based on the data presented in Table 4 for system quality, it shows that most of respondents agreed to the questions regarding the system quality as perceived by them. Respondents were followed by agreed answers had an average score above 4.58, and the percentage of agreed answers were 100 percent for each indicator.

Table 4 - Descriptive Statistics of System Quality

\begin{tabular}{lllll}
\hline Code & Indicator & Average & Agree (\%) & Disagree (\%) \\
\hline SQ1 & Time required to respond to commands on the system must be fasted & 4.65 & 100 & 0 \\
SQ2 & Fashion-renting platform must have system reliability & 4.58 & 100 & 0 \\
SQ3 & Fashion-renting platform must have easy access to the system & 4.71 & 100 & 0 \\
SQ4 & The fashion-renting platform must have a high level of system security & 4.61 & 100 & 0 \\
SQ5 & The system on the fashion-renting platform must be easy to used & 4.76 & 100 & 0 \\
\hline
\end{tabular}

The results of the research survey regarding information quality (IQ) indicators are presented in Table 5. Based on the data presented in Table 5 for information quality, it shows that most of respondents agreed to the questions regarding information quality as perceived by them. Respondents were followed by agreed answers had an average score above 4.42 , and the percentage of agreed answers were above 99.40 percent for each indicator.

Table 5 - Descriptive Statistics of Information Quality

\begin{tabular}{|c|c|c|c|c|}
\hline Code & Indicator & Average & Agree (\%) & Disagree (\%) \\
\hline IQ1 & $\begin{array}{l}\text { Information provided by fashion-renting platform must be accurate and } \\
\text { reliable }\end{array}$ & 4.65 & 100 & 0 \\
\hline $\begin{array}{l}\text { IQ2 } \\
\text { IQ3 }\end{array}$ & $\begin{array}{l}\text { Information provided by fashion-renting platform must be on target } \\
\text { Information provided by the fashion-renting platform must be complete }\end{array}$ & $\begin{array}{l}4.42 \\
4.71\end{array}$ & $\begin{array}{l}99.40 \\
99.40\end{array}$ & $\begin{array}{l}0.60 \\
0.60\end{array}$ \\
\hline IQ4 & $\begin{array}{l}\text { Information provided by the fashion-renting platform must be relevant to the } \\
\text { required }\end{array}$ & 4.53 & 100 & 0 \\
\hline IQ5 & Information provided by the fashion-renting platform must be updated & 4.67 & 100 & 0 \\
\hline IQ6 & $\begin{array}{l}\text { Information provided by the fashion-renting platform should be easy to } \\
\text { understand }\end{array}$ & 4.72 & 100 & 0 \\
\hline
\end{tabular}

The results of the research survey regarding perceived usefulness (PU) indicators are presented in Table 6. Based on the data presented in Table 6 for perceived usefulness, it shows that most of respondents agreed to the questions about perceived usefulness as perceived by themselves. Respondents were followed by agreed answers had an average 
score above 3.79, and the percentage of agreed answers were above 92.50 percent for each indicator.

Table 6 - Descriptive Statistics of Perceived Usefulness

\begin{tabular}{|c|c|c|c|c|}
\hline Code & Indicator & Average & Agree (\%) & Disagree (\%) \\
\hline PU1 & $\begin{array}{l}\text { Using a fashion-renting platform allows me to rent clothes faster than } \\
\text { coming to a boutique or offline store }\end{array}$ & 3.94 & 92.50 & 7.50 \\
\hline PU2 & $\begin{array}{l}\text { Using a fashion-renting platform will improve my effectiveness in renting } \\
\text { clothes }\end{array}$ & 3.98 & 93.60 & 6.40 \\
\hline PU3 & $\begin{array}{l}\text { Using a fashion-renting platform can make it easier for me to choose the } \\
\text { desired clothes }\end{array}$ & 4.07 & 94.80 & 5.20 \\
\hline PU4 & Online transactions using a fashion-renting platform are profitable & 3.79 & 95.40 & 4.60 \\
\hline PU5 & Fashion-renting platform provide useful information for consumers & 4.05 & 97.70 & 2.30 \\
\hline
\end{tabular}

The results of the research survey regarding perceived ease of use (PEOU) indicators are presented in Table 7. Based on the data presented in Table 7 for perceived ease of use, it shows that most of respondents agreed to the questions regarding the perceived ease of use as perceived by them. Respondents were followed by agreed answer had an average score above 4.01, and the percentage of agreed answers ware above 94.80 percent for each indicator.

Table 7 - Descriptive Statistics of Perceived Ease of Use

\begin{tabular}{|c|c|c|c|c|}
\hline Code & Indicator & Average & Agree (\%) & Disagree (\%) \\
\hline PEOU1 & I feel it will be easier to rent clothes online using a fashion-renting platform & 4.02 & 95.40 & 4.60 \\
\hline PEOU2 & I feel that I will find interactions via web pages clear and understandable. & 4.04 & 97.70 & 2.30 \\
\hline PEOU3 & I would find it easy to run the features on the fashion-renting platform & 4.02 & 97.70 & 2.30 \\
\hline PEOU4 & Overall, renting clothes on a fashion-renting platform would be easy for me & 4.01 & 94.80 & 5.20 \\
\hline
\end{tabular}

The results of the research survey regarding user satisfaction (US) indicators are presented in Table 8. Based on the data presented in Table 8 for user satisfaction, it shows that most of respondents agreed to the questions regarding user satisfaction as perceived by themselves. Respondents followed by agreed answers had an average score above 3.86, and the percentage of agreed answers were above 96.50 percent for each indicator.

Table 8 - Descriptive Statistics of User Satisfaction

\begin{tabular}{|c|c|c|c|c|}
\hline Code & Indicator & Average & Agree (\%) & Disagree (\%) \\
\hline US1 & $\begin{array}{l}\text { The variety of clothing choices provided by the fashion-renting platform will } \\
\text { greatly affect my satisfaction }\end{array}$ & 4.24 & 97.70 & 2.30 \\
\hline US2 & Overall I will be satisfied with the use of the fashion-renting platform & 3.86 & 96.50 & 3.50 \\
\hline
\end{tabular}

The results of the research survey regarding attitude (ATT) indicators are presented in Table 9. Based on the data presented in Table 9 for attitude, it shows that most of respondents agreed to the questions regarding attitude as perceived by themselves. Respondents followed by agreed answers had an average score above 3.61, and the percentage of agreed answers were above 90.20 percent for each indicator.

Table 9 - Descriptive Statistics of Attitude

\begin{tabular}{|c|c|c|c|c|}
\hline Code & Indicator & Average & Agree (\%) & Disagree (\%) \\
\hline ATT1 & $\begin{array}{l}\text { I would have had the pleasure of renting clothes using a fashion rental } \\
\text { platform }\end{array}$ & 3.86 & 93.60 & 6.40 \\
\hline ATT2 & Renting clothes through an e-commerce platform is the right choice & 3.61 & 90.20 & 9.80 \\
\hline ATT3 & Renting clothes through an e-commerce platform is very efficient & 3.97 & 96 & 4 \\
\hline
\end{tabular}

The results of the research survey regarding intention to use (BIU) indicators are presented in Table 10. Based on the data presented in Table 10 for intention to use, it shows that most of respondents agreed to the questions regarding intention to use as perceived by them. Respondents followed by agreed answer had an average score above 3.26, and the percentage of agreed answers were above 78 percent for each indicator. 
Table 10 - Descriptive Statistics Variable Intention to Use

\begin{tabular}{|c|c|c|c|c|}
\hline Code & Indicator & Average & Agree (\%) & Disagree (\%) \\
\hline IU1 & I intend to use a fashion-renting platform later & 3.86 & 90.20 & 9.80 \\
\hline IU2 & I intend to recommend other people to use a fashion-renting platform & 3.79 & 91.90 & 8.10 \\
\hline IU3 & I intend to use the fashion-renting platform frequently & 3.26 & 78 & 22 \\
\hline
\end{tabular}

Hypothesis testing is the stage of testing the significance level of the relationships between constructs, which are used as the basis for determining the results of hypothesis testing. This test can be seen from the statistical significance value (t-value), which is above the value of t-table with ( $\alpha 0.05$; t-table 1.96) then the hypothesis is accepted and vice versa. The significance level test can also be done by looking at the p-value, that is, if the p-value is $<0.05$, it can be statistically stated that there is a significant effect of the tested variables. More fully, the results of the significance test can be seen in Table 11.

Table 11 - Hypothesis Test Results

\begin{tabular}{llll}
\hline Hypothesis & Path Coefficient & T-Value & Results \\
\hline H1: System quality (SQ) $\rightarrow$ User satisfaction (US) & 0.060 & 0.633 & Reject H1 \\
H2: Information quality (IQ) $\rightarrow$ User satisfaction (US) & 0.286 & $2.796^{*}$ & Accept H2 \\
H3: Perceived usefulness (PU) $\rightarrow$ Attitude (ATT) & 0.402 & $4.993^{*}$ & Accept H3 \\
H4: Perceived ease of use (PEOU) $\rightarrow$ Attitude (ATT) & 0.484 & $6.104^{*}$ & Accept H4 \\
H5: Perceived ease of use (PEOU) $\rightarrow$ Perceived usefulness (PU) & 0.827 & $31.032^{*}$ & Accept H5 \\
H6: Perceived usefulness (PU) $\rightarrow$ Intention to use (BIU) & 0.082 & 0.826 & Reject H6 \\
H7: User satisfaction (US) $\rightarrow$ Intention to use (BIU) & 0.187 & 1.542 & Reject H7 \\
H8: Attitude (ATT) $\rightarrow$ Intention to use (BIU) & 0.550 & $4.592^{*}$ & Accept H8 \\
\hline
\end{tabular}

Note: $\left.{ }^{*}\right)$ is significant at $t>1.96$.

Based on the summary of the hypothesis test results in Table 11, it is known that of the eight hypotheses proposed, there were five accepted hypotheses and three rejected hypotheses. The latent variable system quality has no significant effect on user satisfaction, while the latent variable information quality has a significant effect on user satisfaction with a path coefficient of 0.286 and a t-count value of 2.796 . The latent variables perceived usefulness and perceived ease of use both have a significant effect on Attitude with path coefficient values of 0.402 and 0.484 , respectively, and t-count values of 4.993 and 6.104 , respectively. The latent variable perceived ease of use also has a significant effect on perceived usefulness with a path coefficient of 0.827 and a t-count value of 31.032 . Then the latent variables, perceived usefulness and user satisfaction, both have no significant effect on intention to use, while the attitude variable has a significant effect on intention to use with a path coefficient value of 0.550 and a t-count value of 4.592 .

Based on the results of the analysis of the indirect effect between variables with the help of the SmartPLS 3.0 software, there are three pathways that are considered to have a significant effect on the intention to use the clothing rental platform. The indirect relationship between variables is listed in Table 12.

Table 12 - Indirect effect between variables

\begin{tabular}{lll}
\hline Specific & Path Coefficient & t-test \\
\hline Perceived ease of use $\rightarrow$ Attitude $\rightarrow$ Intention to Use & 0.266 & $3.804^{*}$ \\
Perceived Usefulness $\rightarrow$ Attitude $\rightarrow$ Intention to Use & 0.221 & $3.136^{*}$ \\
Perceived Ease of Use $\rightarrow$ Perceived Usefulness $\rightarrow$ Attitude $\rightarrow$ Intention to use & 0.183 & $3.097^{*}$ \\
\hline
\end{tabular}

Note: *) Significant at $t \geq 1.96$.

Variable that has the greatest indirect effect on intention to use is perceived ease of use through attitude with value path coefficient of 0.266 and a t-test value of 3.804 . Furthermore, the effect of perceived usefulness on intention to use through attitude is also considered significant with a path coefficient of 0.221 and a t-count value of 3.136. Perceived ease of use also has an indirect significant effect on intention to use through perceived usefulness and attitude with a path coefficient value of 0.183 and a t-count value of 3.097. 


\section{DISCUSSION OF RESULTS}

System Quality on User Satisfaction. Based on the results of hypothesis testing in Table 11, the path coefficient system quality on user satisfaction is 0.060 and the t-statistics value is $0.633<1.96$, which means that $\mathrm{H} 1$ rejected. This shows that system quality has a positive but insignificant effect on user satisfaction, meaning that changes in the value of system quality have a direct effect on changes in user satisfaction, or in other words, if system quality increases, there will be an increase in user satisfaction but not significant. The results of this study are inconsistent with the research conducted by Liang and Chen (2009) and Santouridis et al. (2009) related to the use of websites and the internet which shows that system quality significantly affects user satisfaction. This is presumably due to the respondents' lack of knowledge regarding the systems and services on the fashion-renting platform. Some of the services that respondents may not understand are fitting services, a complaint system in case of damage to rented goods and a system of delivery and return of rented goods.

Information Quality on User Satisfaction. Based on the results of hypothesis testing the effect of information quality on user satisfaction in Table 11, the path coefficient value is 0.286 and the t-statistics value is $2.796<1.96$, which means that $\mathrm{H} 2$ is accepted. These results indicate that information quality has a positive and significant effect on user satisfaction, meaning that changes in the value of information quality have a unidirectional effect on changes in user satisfaction, or in other words, if information quality increases, there will be a significant increase in user satisfaction. This is consistent with the results of research conducted by DeLone and McLean (1992) and the model of Seddon (1997), which concluded that information quality has a positive and significant effect on user satisfaction of information systems.

Perceived Usefulness on Attitude. TAM states that perceived usefulness affects the user's attitude. PU in this study relates the use of a fashion rental platform in making it easy for users to rent clothes according to their wishes. Based on the results of hypothesis testing in Table 11, the path coefficient value is 0.402 with a t-statistics value of $4.993>1.96$, which means that $\mathrm{H} 3$ accepted. This shows that perceived usefulness has a positive and significant effect on attitude. This means that changes in the value of perceived usefulness have a unidirectional effect on changes in attitude or in other words, if the perceived usefulness increases, there will be an increase in level attitude and statistically has a significant effect. These results are consistent with a model of TAM by Davis (1989) which states that the perceived usefulness positive and significant impact on the attitude or the attitude of the users. The results of this study are also in line with the study conducted by Klopping and McKinney's (2004) regarding the use of e-commerce which states that PU has a positive and significant effect on attitudes to online shopping. This means that when consumers' perceptions of the fashion rental platform provide many benefits, their attitude will be more positive.

Perceived Ease of Use on Attitude. TAM states that perceived ease of use directly affects attitude and also has an indirect effect on attitude through PU. Based on the results of hypothesis testing in Table 11, the path coefficient value is 0.484 with the t-statistics value of $6.104>1.96$, which means that $\mathrm{H} 4$ accepted. This shows that perceived ease of use has a positive and significant effect on attitude, meaning that changes in the value of perceived ease of use have a unidirectional effect on changes in attitude or in other words, if perceived ease of use increases, there will be an increase in level attitude and statistically has a significant effect. The results also showed that PEOU had a positive and significant effect on attitude through PU. This is consistent with the TAM model by Davis (1989) and research conducted by Teo et al. (1999), which states that PEOU has a direct and indirect effect on attitude through perceived usefulness.

Perceived Ease of Use on Perceived Usefulness. Based on the results of the hypothesis test of perceived ease of use against perceived usefulness in Table 11, the path coefficient value is 0.827 and the t-statistics value is $31.032>1.96$, then $\mathrm{H} 5$ accepted. These results indicate that perceived ease of use has a positive and significant effect on perceived 
usefulness, meaning that changes in the value of perceived ease of use have a direct effect on changes in perceived usefulness or in other words if perceived ease of use increases, there will be an increase in the level of perceived usefulness and gradually statistics have a significant effect. It can also be interpreted that someone who has a perception of ease tends to easily get a perception of the usefulness or benefits of the fashion rental platform technology. These results are in line with the results of research conducted by Chiu et al. (2009); Farahat (2012); and Amin et al. (2014) which states that perceived ease of use has a significant effect on perceived usefulness. Based on the results of data processing, it is known that the path coefficient value of perceived ease of use against perceived usefulness is 0.827 , which means that the perceived ease of use line has a positive relationship to perceived usefulness in women in the Greater Jakarta area who have never used arental platform clothing. The results of this study are consistent with studies conducted by Hsu and Lu (2004), Lin and Lu (2000), and Davis (1989), which stated that PEOU has a positive effect on PU.

Perceived Usefulness on Intention to Use. TAM framework hypothesizes perceived usefulness as a direct predictor of behavioral intention to use a technology (Park, et al., 2014). The results obtained in this study are not in accordance with the TAM theory, where based on the results of the hypothesis test for perceived usefulness on intention to use in Table 11, the path coefficient value is 0.082 with a value of $t$ - statistics 0.826 which means $<1.96$ then $\mathrm{H} 6$ rejected. This shows that perceived usefulness has a positive but insignificant effect on intention to use, meaning that if there is an increase in perceived usefulness, there will be no significant increase in intention to use. In this case, perceived usefulness is not a determining factor that directly influences the user's intention to rent clothes through a fashion rental platform. This is presumably due to the unfamiliarity of the respondents with the procedure for renting clothes through a fashion rental platform, so it is likely that consumers who need clothing rental services at this time prefer to come directly to the clothing rental outlet rather than rent online.

User Satisfaction on Intention to Use. Based on the results of the hypothesis test user satisfaction on intention to use in Table 11, the path coefficient value is 0.187 and the $t-$ statistics value is $1.542<1.96$, then $\mathrm{H} 7$ rejected. This shows that user satisfaction has a positive but not significant effect on the intention to use a fashion rental platform. This means that if user satisfaction increases, there will be an increase in the level of intention to use, but statistically it does not have a significant effect. This result is not in accordance with the concept of the IS D\&M success model by DeLone and McLean (1992) which states that user satisfaction has a significant effect on intention to use. This is presumably due to other factors that influence consumer interest. Researchers suspect that the majority of consumers will rent clothes if they really need the goods or services. However, in this regard, consumer needs also cannot be a determinant of using a fashion rental platform, there may be other factors such as user attitudes which determine acceptance of renting clothes online or offline. So that user satisfaction is not a determining factor for the intention to use a fashion rental platform.

Attitude on Intention to Use. Ajzen and Fishbein (1977) argue that attitude refers to a person's positive or negative evaluation of certain behaviors. In other words, attitude represents feelings of liking or disliking individuals towards something. Based on the results of the hypothesis test attitude on intention to use in Table 21, the path coefficient value is 0.550 and the t-statistics value is $4.592>1.96$, so $\mathrm{H} 8$ accepted, which means that attitude has a positive and significant effect on intention to use, meaning that changes in value attitude has a unidirectional influence on changes in the intention to use of the clothing rental platform or in other words if the attitude increases, there will be an increase in the level of intention to use and statistically has a significant effect. The results obtained in this study are in accordance with the TAM theory (Davis, 1989), which states that attitude has a positive and significant effect on intention to use.

Attitude in this study was found to be a mediator for other variables that have an indirect effect on intention to use. The variable that has the greatest indirect effect on intention to use is perceived ease of use through attitude with value path coefficient of 0.266 
and a t-count value of 3.804 . If we refer to the results of the previous hypothesis $(\mathrm{H} 6)$, it is found that perceived usefulness did not have a significant direct effect on intention to use, but indirectly perceived usefulness has a significant effect on intention to use through attitude with a path coefficient of 0.221 and the t-count value of 3,136 . That is the perception of the benefits of a positive impact on the attitude that will determine intention to use technology. Perceived ease of use through perceived usefulness and attitude also has a significant indirect effect on intention to use with a path coefficient value of 0.183 and a t-count value of 3.097. This is in accordance with the TAM theory, which predicts PEOU to have a positive and significant effect through PU and attitude (Davis, 1989).

\section{CONCLUSION}

Fashion-renting platform can be an alternative solution to reduce textile waste. However, fashion-renting platforms are a new business model in Indonesia, so it is necessary to carry out further research related to the factors that influence the interest in using fashion-renting platforms. Based on the hypothesis testing and the discussion that has been done, it can be concluded that the latent variable system quality has no significant effect on user satisfaction, while the latent variable information quality has a significant effect on user satisfaction. The latent variables, perceived usefulness and perceived ease of use, both have a significant effect on user attitude, meaning that the better consumer perceptions of the benefits and ease of using a fashion-renting platform will have a positive effect on the user's attitude. In addition, the latent variable, perceived ease of use also has a significant effect on perceived usefulness. Then the latent variables, perceived usefulness and user satisfaction, both have no significant effect on intention to use, while the attitude variable has a significant effect on intention to use.

\section{RECOMMENDATIONS}

Specific research on each fashion-renting platform in Indonesia is recommended considering that each organizer has a different strategy in terms of branding, segmentation, and policy determination. Addition of other variables outside this study is also recommended. Examples of variables that need to be added include rent price, security, delivery and return in terms of rented goods, and analyzing how much consumer interest to make transactions (willingness to pay) using a fashion-renting platform.

\section{REFERENCES}

1. Ajzen I and Fishbein M. (1977. Attitude-behavior relations: A theoretical analysis and review of empirical research. Psychological Bulletin. 84 (5): 888-918.

2. Amin M, Rezaei S, Abolghasemi M. (2014). User satisfaction with mobile websites: the impact of perceived usefulness (PU), perceived ease of use (PEOU) and trust. Nankai Business Review International. 5(3): 258-274.

3. Armstrong CM, Niinimaki K, Lang C, Kujala S. (2015). A Use-Oriented Clothing Economy? Preliminary Affirmation for Sustainable Clothing Consumption Alternatives. Sustain. Dev. 24: 18-31.

4. Bardhi F, Eckhardt GM. (2012). Access-based consumption: The case of car sharing. J. Consum. Res. 39: 881-898.

5. Birtwistle G, Moore C. (2007). Fashion clothing - where does it all end up? International Journal of Retail \& Distribution Management. 35 (3): 210-216.

6. Chiu C, Chang C, Cheng H, Fang Y. (2009). Determinants of customer repurchase intention in online shopping. Online Information Review. 33 (4): 761-784.

7. Davis FD. (1989). Perceived usefulness, perceived ease of use, and user acceptance of information technology. MIS Quarterly. 13 (3): 319-340.

8. DeLone WH and McLean ER. (1992). Information system success: The quest for the dependent variable. Information Systems Research. 3(1): 61-95. 
9. Estelami H. (1998). The price is right...or is it? Demographic and category effects on consumer price knowledge, Journal of Product \& Brand Management. 7 (3): 254-66.

10. Farahat T. (2012). Applying the Technology Acceptance Model to Online Learning in the Egyptian Universities. Procedia - Social and Behavioral Sciences. 64: 95-104.

11. Hsu CL and Lu HP. (2004). Why do people play online games? An extended TAM with social influences and flow experience. Information and Management. 41 (7): 853-868.

12. Klopping IM and McKinney E. (2004). Extending the Technology Acceptance Model and the Task-Technology Fit Model to Consumer E-Commerce. Inf. Technol. Learn. Perform. J. 22: 35-48.

13. Liang C and Chen H. (2009). A study of the impacts of website quality on customer relationship performance. Total Quality Management and Business Excellence. 20 (9): 971-988.

14. Lin JCC and Lu H. (2000). Towards an understanding of the behavioural intention to use a web site. International Journal of Information Management, 20 (3): 197-208.

15. Park N, Rhoads M, Hou J, Lee KM. (2014). Understanding the acceptance of teleconferencing systems among employees: An extension of the technology acceptance model. Computers in Human Behavior. 39: 118-127.

16. [PR Newswire]. (2017). Online Clothing Rental Market is Expected to Reach $\$ 1,856$ Million, Globally, by 2023 - Allied Market Research [internet]. [10 October 2019]. Available at: https://www.prnewswire.com/news-releases/online-clothing-rental-market-isexpected-to-reach--1856-million-globally-by-2023---allied-market-research618522543.html.

17. Santouridis I, Trivellas P, Reklitis P. (2009). Internet service quality and customer satisfaction: Examining internet banking in Greece. Total Quality Management dan Business Excellence. 20 (2): 223-239.

18. Seddon PB. (1997). A respecification and extension of the DeLone and McLean model of IS success. Inf Syst Res. 8 (3): 240-253.

19. Teo TSH, Lim VKG, Lai RYC. (1999). Intrinsic and extrinsic motivation in internet usage. The Internet Journal of Management Science. 27: 25-37. 